\title{
12
}

\section{MANAGING THE CORONAVIRUS PANDEMIC IN A CENTRALISED FEDERAL SYSTEM}

\section{The case of Mexico}

José María Serna de la Garza

\subsection{Introduction}

According to its most recent census, taken in 2010 (the 2020 census was suspended due to the pandemic), Mexico has a population of 120 million people. Of this count, 25.694 million (21.5 per cent of the total) consider themselves members of the indigenous population, with 7.3 million people over the age of 3 years speaking a Native-American language - of them, 12 out of every 100 do not speak Spanish. Around 77.8 per cent of Mexicans live in urban areas, and the balance of 22.2 per cent in rural areas (INEGI 2010), yet in spite of this high rate of urbanisation, the population is dispersed across a territory almost 2 million $\mathrm{km}^{2}$ in size and characterised by great geographical diversity, as a result of which there are important regional differences in cultural and political identity. These differences, however, have not led any subnational community to claim recognition as a 'nation within the nation' (as happened, for example, with Catalonia in its relationship with Spain), nor does any component of the Mexican union demand secession.

Mexico's rather centralised federation consists of 31 states, Mexico City (which has a different status), and 2,457 municipalities. The origins of its centralisation lie in the hegemonic party system that prevailed between 1929 and 2000. In this system, an all-powerful president led a party that controlled most of the political positions at national and subnational level, subordinated state and municipal authorities to his will, and centralised the federal arrangement by way of formulas for allocating powers and sharing fiscal revenue (Cabrero Mendoza 2013). To this day, the logic of centralisation persists in the institutional and normative design of what is otherwise a competitively multiparty federal system.

Mexico's first case of Covid-19 - a 35-year-old man who had travelled from Italy to Mexico - was reported on 28 February 2020 in Mexico City, and its first 
fatality, on 18 March. During 2020, there were more than 90,000 deaths from Covid-19. States and municipalities were the first to take steps to combat the pandemic; as for the federal government, it espoused a policy of denialism until it became evident that Mexico (and the rest of the world) was facing a global health crisis. After numerous social and economic activities were placed under lockdown, a gradual reopening began in June of the year, though the pace and rhythm of the lockdown and reopening were a matter of dispute between the federal and state governments.

This chapter examines the actions and decisions that federal, state, and municipal actors took during the 2020 pandemic within the applicable constitutional and legislative framework. The general goal is to identify what can be learnt about Mexico's federal system by analysing their behaviour; the argument made is that, in spite of a centralised federal system, states and municipalities played a significant role in combating Covid-19, thus reinvigorating that system.

The study covers the period from 18 March to 31 October 2020. During this period, in which the initial shock of the pandemic occurred, it was possible to observe key federal issues play out in regard to the distribution of powers and responsibilities and intergovernmental relations in the context of fighting the pandemic; in addition, demands and proposals were made for aspects of the federal system to be changed, chiefly ones relating to fiscal federalism.

\subsection{The federal constitutional and legislative framework}

\subsubsection{Division of powers and functions}

The principle by which powers and competences are allocated in Mexico's federal system is found in the residual clause of article 124 of the Mexican Constitution of 1917, according to which the powers not expressly attributed by the Constitution to the federal authorities are reserved to the states or Mexico City. There is a long list of such federal powers (Serna de la Garza 2013: 134-161). However, a number of policy areas are subject to a regime of concurrent powers, which entails that the Federal Congress can pass a statute distributing competences and responsibilities between the two (or among the three) levels of government - municipalities are recognised under article 115 of the Constitution as a third order of government.

Matters of 'general health' are subject to a regime of concurrent powers. The General Law on Health of 7 February 1984, passed by the federal Congress, distributes competences between the federal and state authorities in connection with different aspects of public health care. The federal government, through the Ministry of Health, has the power to issue general guidelines for the provision of public health services, powers of coordination of the National Health System, ${ }^{1}$ and inspection powers to verify compliance with those guidelines. Moreover, the General Law on Health provides powers to the states in regard to the operation of public health services within their territories (González Block 2020). 
The federal government provides health services and social security to two categories of insured people: private sector employees, through a federal entity called the Mexican Institute of Social Security (IMSS), and federal government employees, through the Institute for Social Security and Services for State Workers (ISSSTE). Some federal ministries or agencies have health services and social security schemes of their own for their employees. For their part, state governments likewise provide health services and social security for state employees. In addition, they have operative powers to provide public health services to the 'open' population, that is to say, to uninsured people.

Municipal governments do not have direct competence in the provision of health-care services, but do have constitutional powers that have an impact on public health, given that they are in charge of a variety of public functions and services. These include drinking water, drainage, and sanitation; street lighting; refuse removal; municipal markets and wholesale markets; cemeteries; slaughterhouses; streets, parks, and gardens; and public security, including preventative policing and traffic police (Graizbord 2009).

Public education is a subject matter that likewise falls under a regime of concurrent powers. In this regard, the General Law on Education of 30 September 2019 distributes competences and powers in this field among the different orders of government. Broadly speaking, the federal government, through the Ministry of Public Education, has the power to carry out global planning and programme direction of the national education system for the provision of public education, further to which it has powers of inspection over federal and state public schools as well as private education institutions; as for states, they are in charge of managing public state schools of the different levels of government.

\subsubsection{Declaration of national disasters or states of emergency}

Article 29 of Mexico's Constitution establishes a procedure for suspending or restricting rights by means of a declaration of a national disaster or state of emergency. In terms of this procedure, the President must obtain the approval of the Congress of the Union for such a declaration. The mechanism in article 29 has been activated only once, in the context of the Second World War, and was not to put to work during the Covid-19 crisis. Neither the states nor municipal governments have constitutional powers like these. States do not have the opportunity to participate in the procedure foreseen in article 29. This procedure is exclusively in the hands of federal entities, namely, the President of the Republic and the Congress of the Union.

In regard to disaster management, civil protection is a matter that falls under a normative regime of 'coordination', which is different from the regime of 'concurrency'. Under the latter, the federal Congress can pass a statute that distributes powers and competences among the different orders of government in a specific subject matter. Under 'coordination', the federal Congress does not distribute 
powers but creates mechanisms of coordination and collaboration among orders of government in a specific policy area (Serna de la Garza 2009). Accordingly, the General Law on Civil Protection of 6 June 2012, passed by the federal Congress, creates a system of coordination and collaboration between federal, state, and municipal authorities to react in cases of natural or man-made disasters. This system was, however, not put to use during the 2020 pandemic.

Article 73(XVI) of the Constitution defines two authorities that have the power to make decisions in a health crisis: the Ministry of Health and the Board of General Health. Both have the power to issue orders and provisions of mandatory compliance by the authorities of the three orders of government in the event 'of a serious epidemic or risk of invasion of exotic diseases'.

\subsubsection{Health in the constitution and statute law}

According to article 4(4), of the Constitution,

[e]very person has the right to health protection. The law shall determine the bases and terms to access health services and shall establish the concurrence of the Federation and the States in regard to general health according to the item XVI in Article 73 of this Constitution.

In its development of this constitutional regime of concurrence, the normative scheme established by the General Law on Health in connection with fighting a pandemic can be summarised as follows: If a communicable disease threatens to become a serious danger in the territory of a state, the state authorities, in exercise of the reserved powers they enjoy in accordance with the logic of article 124 of the Constitution, can take such health measures as they are entitled to under the local legal order. Furthermore, this is particularly the case if, for some reason, the Federal Ministry of Health and the Board of General Health decide not to exercise their powers in the matter (e.g. if they regard the disease not as a threat to the general health of the republic, but as a problem limited to the territorial scope of a state). However, if the Ministry of Health and/or the Board of General Health decide/s to exercise their powers in this matter, then the state authorities must be subject to the general provisions, measures, and actions that these federal bodies dictate in addressing the health emergency.

\subsection{Preparedness for a national disaster: The institutional framework}

Normatively speaking, the Board of General Health has an intergovernmental dimension inasmuch as some state ministers of health form part of its structure and participate in its sessions, with voice though without vote. In theory, then, the Board should function as a forum for intergovernmental relations. However, in practice it does not function in a collegiate way, given that its decisions are 
taken by the Federal Ministry of Health. Prior to the 2020 pandemic, the last time the Board of General Health and the Ministry of Health issued general norms to control a pandemic was in 2009, in the context of the H1N1 influenza.

There is also a Federal Aid Plan for the Civilian Population in Disaster Cases known as the DN-III Plan, which is a military operational instrument that establishes general guidelines for the Mexican army and navy to carry out relief activities if the population is affected by disasters of natural or human origin. Its legal basis is in articles 21 and 73 of the General Law on Civil Protection and article 1 of the Organic Law of the Mexican Army and Air Force.

\subsection{Rolling out measures to contain the pandemic}

When the pandemic struck, party-political contestation was already much in the foreground, so governors and legislators duly responded to the crisis along party lines. ${ }^{2}$ Supporters of the President, Andrés Manuel López Obrador, and his party, the Movement for National Regeneration, or Movimiento de Regeneración Nacional (MORENA), followed federal directives and guidelines with little criticism, although there were a few exceptions. ${ }^{3}$ For their part, governors within the opposition established different groups (four in total) to form a common front in resisting particular federal directives.

These groups were organised along party and regional lines, with the most visible of them being the so-called Federalist Alliance. Made up of 10 governors, it drew together opposition parties on the left, centre, and right of Mexico's political spectrum. Its members were the governors of Aguascalientes (PAN), Coahuila (PRI), Guanajuato (PAN), Jalisco (MC), Colima (PRI), Michoacán (PRD), Nuevo León (no party affiliation), Tamaulipas (PAN), Chihuahua (PAN), and Durango (PRI). In September 2020, they decided to withdraw from the National Conference of Governors - which has represented all state governors since the early 2000 s - on the grounds that it did not defend the sovereignty of the states, operate effectively, or serve as a forum for dialogue with the federal executive. $^{4}$

The pandemic not only deepened political divisions but also further marginalised Mexico's indigenous peoples. Many such communities lack clinics, as a result of which some of them closed access to their towns or locales as the only way to avoid infection. Many of them had also not received information in their own languages on how to take care of themselves during the pandemic. For example, the leader of the Council of Community Government of Chilón, which represents about 600 communities of the Tzeltal ethnic group, accused health authorities of having done nothing to help them. Under circumstances like these, indigenous peoples resort to traditional medical practices but still claim for more assistance from health authorities. The Nich Ixim Midwife Movement of Chiapas, which advocates on behalf of indigenous midwives in the state of Chiapas, sought to guide community members on how to implement prevention measures in the absence of resources such as sanitisers and masks. 
Such communities generally lack clinics, health services, and regular access to water and are challenged by linguistic barriers, inequality, exclusion, and historical neglect. During the pandemic, many were demanding that authorities at least provide mobile clinics, along with appropriate personnel and equipment (Reforma, 19 April 2020: 10). In the face of inaction by health authorities, some local authorities, such as the municipality of Ometepec (in the state of Guerrero), denied access to non-residents and imposed evening curfews, with sanctions of arrest of up to 36 hours for transgressors.

\subsubsection{Taking the initiative}

Some states, and even municipal authorities, were the first to take measures to combat the pandemic. On 13 March 2020, while the federal government was still denying the dangers of Covid-19, the governor of Jalisco, Enrique Alfaro, a member of the centrist opposition party Movimiento Ciudadano (MC), announced a number of response measures (Reforma, 18 March 2020: 1). First, he set up a panel of experts with advisory functions and, secondly, a coordination mechanism for engaging with municipal governments and academic institutions to reach consensus on what to do. On the same day, Alfaro announced the postponement of mass events including a film festival and pre-Olympic football tournament. On 15 March, he suspended in-person classes in state public schools and ordered the use of Covid-19 screening and sanitisation stations at state airports and bus stations.

Similarly, on 17 March 2020 both Alfaro and the governor of Nuevo Leon ordered the closure of public places such as bars, casinos, cinemas, and restaurants. At the local level, the municipal government of San Pedro Garza García (in the state of Nuevo León) also reacted rapidly. On 17 March 2020 it declared a 'state of emergency', ordering measures that included the temporary closure of bars, clubs, discos, breweries, gyms, and places of worship, as well as the cancellation of permits for all public and private events in public spaces (Reforma, 18 March 2020: 1).

Alfaro's precautionary measures drew criticism from the Federal Ministry of Health, which at that early, uncertain point in the pandemic deemed the state of Jalisco's actions as unnecessary. Federal-state tensions continued to rise, though, when the governor of Jalisco announced a programme of rapid tests for the coronavirus, thereby contradicting a federal policy stance that, then as later, gave little to no credence or importance to testing. Finally, on 16 April 2020, the Ministry of Health accused the government of Guadalajara (the capital city of Jalisco) of not complying with suspension of non-essential commercial activities as ordered by federal authorities (Reforma, 18 April 2020: 7).

In spite of the fact that the first infection in Mexico was reported on 27 February 2020, during the next 30 days the federal government continued allowing mass events and football games of the national league. Likewise, the President continued attending public meetings, shaking hands, and kissing people without him or other participants wearing face masks. On 22 March he was still inviting Mexicans to go out in the streets and dine at restaurants to 
strengthen the economy (Reforma, 13 May 2020: 12). The first action by the federal government came only on 30 March 2020, when the Board of General Health issued a decree by which a health emergency of force majeure was declared. One day later, the Ministry of Health issued a decree enumerating extraordinary actions to address this emergency. Among other things, the public, social, and private sectors had to implement measures that included the 'immediate suspension of non-essential activities'.

\subsubsection{Federal action}

\subsubsection{Initial federal action}

The Board of General Health's Declaration of Emergency was published on 30 March 2020. The main purpose of this Declaration was to open the door to the Extraordinary Measures taken by the Ministry of Health, which were published on 31 March. The latter ordered the immediate suspension of 'non-essential' activities for one month (the decree provided a list of activities considered 'essential'); set out rules on how to organise work in places where essential activities were allowed (concerning the number of people allowed in the workplace and the sanitary and control measures to be taken); and instructed people to stay at home. The decree also stated that the Ministry of Health, in conjunction with the Ministry for Economic Affairs and Ministry of Labour and Social Welfare, would issue guidelines for the country's orderly, phased, and regionalised return to work and social and economic activity (Ministry of Health 2020).

On 21 April 2020, another decree by the Ministry of Health extended the extraordinary measures for two months (until 31 May) and imposed a number of duties on state governments. Among other things, state governments were to keep a registry of patients in hospital with acute respiratory infections; implement prevention and control measures in line with the criteria issued by the Ministry of Health; establish mechanisms for restricting the municipal-level mobility of persons infected by or exposed to Covid-19; report to the Federal Ministry of Health on the implementation of these measures; and supervise changes to hospitals to guarantee the availability of beds for treating infected patients.

In addition, Aid Plan DN-III, mentioned earlier, was activated so as to make military hospitals available for patients with Covid-19; to make military personnel available to operate and protect hospitals; and to provide support in food distribution, transportation of supplies, repatriation of compatriots, and manufacture of medical supplies.

\subsubsection{Federal-state conflict about reopening}

In the same way as there were conflicts about the imposition of the lockdown, so there was conflict when it came to reopening schools and the economy. On 13 May 2020, the federal government announced its strategy for enabling the 
country to resume social and economic activity. This was to extend across three stages, each entailing a 'traffic-light' system of four phases (red, orange, yellow, and green), and to begin on 1 June.

GOAN, the association of nine governors from the opposition party PAN, reacted to the strategy on Twitter, saying in effect that its member states would heed their own counsel and decide for themselves when to reopen their states, taking into account local conditions and the advice of experts. The President replied that there would be no fight with the states in the event that their governors did not comply with the federal reopening plan:

If there is a municipal or state authority that according to the characteristics of their own region or of each state, decides that they will not comply with the plan, there will be no controversy.... Though the plan was agreed in general, it also allows discrepancies, the right to think differently.

(Reforma, 14 May 2020: 5)

Likewise, the Ministry of Health conceded that decisions on reopening according to the 'traffic-light' system would depend on the conditions in each state. States would be able to increase restrictive measures but not make them less restrictive or more flexible. Consensus, the Ministry said, had been reached on the issue (Reforma, 3 June 2020: 1).

The federal government and state governors also differed on the date on which to resume in-person classes in private and public schools. Initially, the Federal Minister of Education set 1 June 2020 as the date on which this would come to pass throughout Mexico. Numerous governors disagreed, arguing that in view of the differing conditions in the states, the decision to reopen schools should be taken by the authorities of each state. Ultimately, the Minister had to accede to this position (Reforma, 14 May 2020: 3).

\subsubsection{Legal challenge by indigenous peoples}

Flaws in the inclusivity and efficacy of Mexico's federal system, specifically when placed under the strain of pandemic crisis management, were highlighted in a number of legal challenges that communities of indigenous peoples mounted in reaction to alleged acts or omissions by the federal government in responding to Covid-19.

In one case, for example, the indigenous peoples of the Tsotsil, Tzeltal, Zoque, and Chol ethnic groups successfully filed a writ of amparo ${ }^{5}$ demanding a guarantee of access to information about Covid-19 and its prevention in their respective home languages (Reforma, 8 April 2020: 1). In another, the Pueblo Maya Ch'ol (who reside in the municipalities of Palenque, Ocosingo, and Salto del Agua in the state of Chiapas) filed a writ of amparo against the continuation of a federal mega-project involving the construction of a railway line in the Southeast states. Here, the district judge ruled that the federal government had to desist from the project in the affected municipalities while the pandemic lasts, since 
continuation of work endangered the lives and health of the local population (Reforma, 23 June 2020: 1).

\subsubsection{Accountability and the separation of powers}

Mexico's pandemic response served to centralise power even further in the federal executive in the context of a system that, even before the health crisis, was focused on the President.

The two chambers of Congress stopped meeting from the end of March 2020, returning to work, albeit in a limited way, by mid-June. As a result, health measures and those related to mitigating the economic effects of the pandemic were adopted by the President and Ministry of Health with little deliberation. Especially controversial was the President's proposal, sent to Congress on 23 April 2020, which sought to empower him, in case of 'economic emergencies in the country', to 'redirect resources of the federal Budget, to allocate them to maintain the execution of the projects and priority actions of the Federal Public Administration and promote the country's economic activity, to face health emergencies and finance programs for the benefit of society' (Parliamentary Gazette 2020).

This proposal was not discussed in Congress - not only because of the difficulties of having meetings, but because the proposal was presented seven days before the end of the regular session of the Federal Congress, which each year begins on February 1 and ends on April 30. The proposal represented an attempt to take advantage of the crisis and absorb powers which are exclusive to the Federal Chamber of Deputies, such as the power to approve the federal budget. Furthermore, in the proposal, the power to declare when there is an 'economic emergency' was entirely at the discretion of the federal executive.

Apart from the case of the governor of Michoacán (mentioned below), there were cases in which federal courts were asked to clarify whether municipal governments have powers to establish harsh restrictions on the freedom of movement. The Courts determined that, according to the Constitution, municipal authorities are not allowed to suspend or restrict human rights.

\subsubsection{State action}

Some states asserted their autonomy with regard to their responsibilities and resisted being directed by the federal government. This is generally true for governors from opposition parties, as the examples below suggest.

\subsubsection{Health measures}

On 17 April 2020, the government of the state of Mexico, via its Ministry of Security, paroled 1,894 prisoners to avoid infections in state prisons. The releases were approved by the state Superior Court of Justice, which examined the proposal and allowed prisoners sentenced for 'non-serious' crimes (i.e., ones entailing 
a prison sentence of less than 5 years) to be paroled subject to their wearing electronic bracelets. On the same day, the federal government announced that it was considering paroling inmates in federal prisons and, to this end, utilising the President's power of pardon.

On 25 June 2020 the government of Hidalgo established, in the state's capital city of Pachuca, the first of 30 health units to apply quick and free tests for Covid-19 (this, contrary to federal policy that denied the usefulness of tests) (Reforma, 26 June 2020: 6). Three days later, the same initiative was implemented in the rest of the state. A similar policy was implemented in an important tourist centre, namely Acapulco in the state of Guerrero.

\subsubsection{Lockdown and mobility measures}

The governor of Jalisco rejected the possibility of returning to in-person classes on 1 June 2020, as ordered by the federal government. This contradicted what the Federal Ministry of Education had declared regarding a possible return to classes on 1 June or 17 July. Jalisco suspended classes on 17 March and resumed them online on 17 April.

While the federal government was working out its plans and timelines for the resumption of schooling, opposition governors announced unilateral decisions to finish the then-current cycle and begin the next one. The governor of Jalisco said that in spite of a decrease in infections in the state, there would not be a return to in-person classes, as his government did not want to run any risks. Classes, he said, would continue online or on television by way of programmes such as Recrea Digital and Learn at Home (Reforma, 12 May 2020: 2).

Although federal policies entailed voluntary rather than mandatory confinement, some governors adopted more restrictive measures that indeed required mandatory confinement, giving rise to lawsuits that claimed these measures were unconstitutional. For example, on 20 April 2020, the governor of Michoacán issued a decree declaring mandatory isolation and imposing strong restrictions on people's mobility, along with sanctions for those who violated them. The decree was challenged by a group of academics at the Faculty of Law of the Nicolaita University of Michoacán, who filed a writ of amparo against it. However, in the end the collegiate circuit court that heard the case decided in favour of the governor, on the ground that the contested decree aimed to protect social well-being. ${ }^{6}$

Only a few states imposed border controls. For example, the government of Tamaulipas did so on the state's border with Nuevo León to prevent the entry of vehicles and persons deemed 'non-essential' (Reforma, 17 April 2020: 2).

\subsubsection{Economic measures and reopening}

In May 2020, Jalisco announced a plan for its economic recovery. Entitled Plan de Reactivación Económica, its main thrust was to revise the state budget by taking austerity measures. The governor requested that the state executive, legislature, and 
judiciary draft a plan to save money given that the pandemic had led to a major shortfall in a state budget of more than MXN 3 billion (Reforma, 2 May 2020: 3).

In the same month, the governors of Coahuila, Colima, Michoacán, Nuevo León, Tamaulipas, and Jalisco collectively determined their reopening plans. At a meeting on 15 May 2020, they agreed to work to a common agenda prioritising health, economic recovery, and assistance for the poor. An underlying premise of their collaboration was - as opposition governors argued on another occasion in a virtual meeting with federal authorities - that it is state governments, not the federal government, that have full knowledge of the conditions in their respective territories (Reforma, 16 May 2020: 1).

Even the governor of Puebla, a member of the same party as President López Obrador, announced that his state would have its own 'traffic-light' system for reopening. Although it would be similar to the federation's, he asserted that the 'new normality' in Puebla had to be defined by this state's own criteria. The governor said he did not want to be left waiting to take the lead from the federal government on the basis of assessments that were unrelated to circumstances in places where the real fight against the virus was being waged (Reforma, 23 May 2020: 3).

\subsubsection{Cooperation among states}

As has been suggested already, various states engaged in horizontal cooperation with each other along regional and political lines. For instance, in May 2020, the governors of Jalisco, Aguascalientes, Querétaro, and San Luis Potosí decided on a series of measures for addressing the pandemic in a coordinated manner, with such measures including reinforcing Covid-19 screening and sanitisation stations and devising ways to support the automobile and electrical industries. These states formed a regional alliance, the Alianza Centro-Bajio-Occidente, and agreed to assist one another with medical resources for their hospitals (Reforma, 1 May 2020: 8).

In addition, after initiating their own reopening plans, eight governors met in the state of Nuevo León to share their experiences on the matter and agree on simplified requirements for allowing businesses to reopen. According to the governor of Nuevo León, this involved using a system of 'economic intelligence' to monitor the impact of economic reactivation. He said the governors at the meeting agreed to support small enterprises through credit from public and private financial institutions and thus enable them to integrate themselves into the value chains of larger companies.

The governors present in the meeting were those of Tamaulipas, Coahuila, Jalisco, Michoacán, Durango, and Guanajuato. This bloc, located in the Northeast of the country and cutting across political parties, said it would seek a meeting with another regional alliance of governors, the Alianza Bajio-Centro-Occidente, to exchange information about what they had learnt from their experiences. 
For their part, the nine opposition governors of GOAN proposed common areas of action in regard to economic reactivation. For example, they put forward a national strategy to address the economic crisis caused by the pandemic. It included creating an unemployment insurance scheme, implementing a programme of temporary employment, introducing tax incentives for new businesses, and providing soft loans for companies.

\subsubsection{Local government action}

The role of local authorities during the 2020 pandemic was mostly confined to implementing measures decided upon by the federal and state governments. There were exceptions to this, however. For example, in early March a number of municipalities took the initiative to shut down activities in public places; others yet, as mentioned, illegally closed their borders with other municipalities.

In this respect, the mayors of various municipalities disregarded the directives of the Federal Minister of the Interior, who told them not to limit freedom of movement in their goal of curbing infections. She explained to them that the federal government had authorised neither a curfew nor a suspension of rights; what it decreed was instead a health emergency in which Mexicans were requested to stay at home voluntarily. As such, municipalities could not close their 'borders', that is, their territorial limits, albeit that this is what happened in the states of Veracruz, Tamaulipas, Coahuila, and Nuevo León (Reforma, 25 April 2020: 7).

Another trend during the period was that mayors of the same party affiliation endeavoured to work together to leverage greater financial resources from the federation. For example, due to the fact that the income municipalities derived from municipal taxes decreased by 50 per cent as a result of the pandemic, mayors of the Federación Nacional de Municipios de México (FENAMM), linked to the Institutional Revolutionary Party, and of the Asociación Nacional de Alcaldes (ANAC), linked to the Party of National Action, asked the Federal Ministry of Finance to flexibilise the use of federal transfers and to authorise extraordinary transfers. The same was proposed by the Asociación de Autoridades Locales de México (AALMAC), which represents mayors from the ruling MORENA party at federal level (Reforma, 9 June 2020: 5).

Generally, the impression gained from media coverage of the pandemic is that there was a suspension of the usual modes by which executive mayors are held accountable, given that various municipal councils temporarily ceased operations. By the same token, many others decided to conduct their sessions online, while others yet resumed in-person sessions, with strict sanitary measures being observed. Nonetheless, the scope for public accountability diminished, particularly in those municipalities where there is the option of having public and open sessions of the municipal council. 


\subsubsection{Intergovernmental relations}

Coordination among the different levels of government was patchy, if not dysfunctional. It is worth noting generally that Mexico lacks an institutional forum in which the federal executive can meet regularly with governors to reach consensus on public policies in matters related to health and education, among other things (see Hopkins 1990; Rodríguez 1998; Ward and Rodríguez 1999). Some governors had been requesting a meeting with the President since December 2019, without success. That meeting finally took place on 19 August 2020, by which point the country was nearing a total of 60,000 deaths from Covid-19.

In particular, there was a notable lack of communication between the Federal Health Ministry and state governments about 'general health', which is a concurrent responsibility of the federal and state governments. In the case of pandemics like Covid-19, the Ministry of Health may adopt 'extraordinary measures' in regard to health, with state governments then obliged to follow federal guidelines. However, what was witnessed throughout the crisis was a series of conflicts, disagreements, and failed encounters between federal and state authorities with regard to, inter alia, the point at which to declare a health emergency; the kinds of health-protection measures to adopt; and the timing and pace of reopening the national economy.

This was due in large part to the non-existence of an institutional mechanism to facilitate communication between the President and state governors and harmonise the development and implementation of public policy in the federation. Consequently, the lack of effective coordination and cooperation between the federal and state governments was evident from the outset of the 2020 pandemic by mid-March 2020, state governments had taken the first measures to curb the spread of the virus, whereas the Federal Board on General Health did not meet until 19 March (and then only so as to make an evaluation of the situation).

An example of the disagreements between federal and state authorities occurred in mid-April when, after receiving federal aid in the form of materials to use in combating the pandemic, the governors of Michoacán, Aguascalientes, and Quintana Roo complained that the materials were of bad quality and returned them to the federal government as useless.

In another example, on 21 April 2020, the President threatened to expose those governors who did not comply with the measures stipulated by the federal government. He also said his government would not authorise the use of curfews, the police force, or monetary fines in the enforcement of those measures. On the next day, the spokesperson of the presidential office made public a list of municipalities that were not complying with the federal government's instructions to reduce the mobility of persons and have them stay at home. He said, however, that the vast majority - 97 per cent - were compliant. Some of the 'accused' municipalities responded to this by denying the charge and others, by adopting more effective measures for reducing mobility (Reforma, 23 April 2020: 3). 
If the Covid-19 pandemic has taught us any lesson, it is the need to design better coordination and cooperation mechanisms between the three orders government of Mexico's federal system.

\subsubsection{Intergovernmental fiscal relations}

In economic affairs, the federal government has broad powers since it controls both monetary and fiscal policy, with the latter especially centralised given that 90 per cent of fiscal income comes from federal taxes, 8 per cent from state taxes, and 2 per cent from municipal taxes. States and municipalities are highly dependent on federal transfers to fund their activities in that they have only limited taxation powers. The transfers are the so-called 'participaciones' (for discretionary use by state and municipal governments) and the 'aportaciones' (restricted to the specific purpose defined by federal law). These federal transfers represent about 80 per cent of states' fiscal income. ${ }^{7}$ Of the total federal transfers to the states, 42.9 per cent correspond to 'participaciones' and 37.3 per cent to 'aportaciones' (Centro de Estudios de las Finanzas Públicas 2019: 6)

By the end of April 2020, a group of opposition governors had begun to call into question the existing federal fiscal arrangement. The governors of Chihuahua (PAN), Nuevo León (no party affiliation), Tamaulipas (PAN), Jalisco (MC), and Coahuila (PRI) alleged that although their states contribute the most to the federal treasury, they receive the least in federal transfers. After proposing a national debate on this matter, they agreed to postpone it and instead work together in the next general election (2021) to win a majority in the Chamber of Deputies and use that majority to propose a change to the fiscal pact (Reforma, 20 April 2020: 1).

Opposition governors also started to demand more federal resources to fight the pandemic, arguing that 'extraordinary' federal resources were needed to address an extraordinary situation. However, the President's response was that they should reduce their spending and save money in order to procure those resources.

Finally, the governors of Nuevo León (no party affiliation), Tamaulipas (PAN), Coahuila (PRI), Durango (PRI), and Michoacán (PRD) - all with different political affiliations but sharing a regional interest - agreed to do a count of the expenses incurred to face the pandemic and claim reimbursement from the federation. They said that they had faced the crisis with their own ordinary resources and that these resources had to be reimbursed. In their view, it was not possible to face an extraordinary situation with ordinary resources.

The rather centralised arrangement of Mexico's fiscal federalism dates back to three national fiscal conventions that took place in 1925, 1933, and 1947. Today, and as a consequence of tensions derived from the pandemic, some opposition governors have proposed calling a new national fiscal convention, in order to review the rules and principles of the existing fiscal arrangement. 


\subsection{Findings and policy implications}

Mexico has long had a highly centralised federal system, but it was during the 2020 pandemic that the shortcomings of centralisation in such a large and diverse country came fully to light. The federal government has broad legal powers in the fields of health and education, as well as in matters to do with reopening the economy. However, in spite of those powers, a good number of governors took the initiative to decide when to shut down their states' economies and schools, adopted public health measures contrary to federal guidelines (e.g., quick and large-scale testing for Covid-19), or decided for themselves when and how quickly economies should be reopened to suit the circumstances of their respective states.

The pandemic also revealed the displeasure numerous governors feel in connection with the fiscal arrangement in the country's federal system. This arrangement, which dates from the 1980s, is based on the premise that states have waived their powers to create state taxes by ceding them to the federal government in exchange for federal transfers. However, the arrangement has contributed to the subordination of the states to the federation, since the latter has an important margin of discretion in the distribution of federal transfers to the states. Moreover, states that contribute the most to the federal treasury contend that they are not adequately recompensed by what they get back in federal transfers.

Opposition governors of 12 states maintained that, due to a lack of a rational response to the pandemic and the lack of a plan for the economic reactivation of the federation, Mexico needs to move to a new federalism based on a new fiscal pact. This was declared by the governors who comprise the Alianza Centro Bajio Occidente and the Alianza Federalista. In a joint statement, they 'expressed the importance of advancing to a new cooperative and responsible federalism, that is, to a new model of decentralization articulated around powers, responsibilities and duties clearly defined that allow the strengthening of local capacities'. The statement continued:

This new federalism will ... take the maximum advantage [of] the USMCA, ${ }^{8}$ [and] accelerate the country's economic recovery, the strengthening of public finances and the promotion of public and private investment in infrastructure and in public services.

(Reforma, 4 July 2020: 11)

Whether this will happen or not will depend largely on the balance of power that emerges from the electoral processes of 2021, in which the 500 seats of the Chamber of Deputies and 15 governorships will be at stake. At the time of this writing, 14 of those governorships were controlled by opposition parties. If López Obrador's party wins these elections, the Alianza Federalista in favour of a 'new federalism', a 'new fiscal pact', and decentralisation will be severely weakened. 


\section{Notes}

1 The national health system is made up of public administration agencies and entities at the federal, state, and local levels; individuals and organisations in the private sector and civil society that provide health services; and mechanisms for coordinating action. The system aims to fulfil the right to health protection (General Law on Health, article 5) and seeks to harmonise the programmes of the different public (federal and state) and private entities that provide health services in Mexico.

2 In March 2020, the political affiliations of Mexico's 31 governorships were as follows: Partido Revolucionario Institutional (PRI), 12; Partido de Acción Nacional (PAN), 9; MORENA, 7; Partido de la Revolución Democrática (PRD), 1; Movimiento Ciudadano (MC), 1; and one governor with no party affiliation. The percentage of seats in the Chamber of Deputies was MORENA, 50.4 per cent; PAN, 15.4 per cent; PRI, 9.6 per cent; Partido del Trabajo (PT), 9.2 per cent; MC, 5.4 per cent; Partido Encuentro Social (PES), 4.8 per cent; PRD, 2.4 per cent; and Partido Verde Ecologista de México (PVEM), 2.2 per cent; three deputies had no party affiliation. The split in the Senate was MORENA, 42.6 per cent; PAN, 19.5 per cent; PRI, 10.1 per cent; PT, 4.6 per cent; MC, 6.2 per cent; PES, 3.1 per cent; PRD, 2.3 per cent; and PVEM, 5.4 per cent; one senator had no party affiliation.

3 At the outset of the pandemic, the governing party MORENA and its allies (PT, PES, and PVEM) had a comfortable majority in both chambers of Congress, controlling 66.6 per cent of the seats in the Chamber of Deputies and 55.7 per cent of the seats in the Senate. The legislators of these parties have been always ready to cooperate with President López Obrador, and this support did not wither away as the pandemic continued.

4 The other three groups were the Alianza Noreste-Pacifico, comprising seven opposition governors (from Nuevo León (no party affiliation), Coahuila (PRI), Durango (PRI), Tamaulipas (PAN), Jalisco (MC), Colima (PRI) and Michoacán (PRD)); the Alianza Centro-Bajio-Occidente, comprising five opposition governors (from Aguascalientes (PAN), Guanajuato (PAN), Jalisco (MC), Querétaro (PAN) y San Luis Potosí (PRI)); and the Asociación de Gobernadores de Acción Nacional (GOAN), comprising the nine governors of the PAN.

5 A petition for a writ of amparo, or an amparo action, is, according to the Supreme Court of the Philippines (n.d.), 'a remedy available to any person whose right to life, liberty and security is violated or threatened with violation by an unlawful act or omission of a public official or employee, or of a private individual or entity'.

6 See Amparo 403/2020, filed by Jorge Alvarez Banderas against the decree of 20 April 2020 by the governor of Michoacán, which declared mandatory confinement as a measure to combat the pandemic.

7 See generally Cabrero Mendoza (2013) and Gershberg (1995); for a constitutional and comparative perspective, see Serna de la Garza (2000).

8 The United States-Mexico-Canada Agreement (USMCA) is a free-trade agreement in force since March 2020; it replaces the North American Free Trade Agreement (NAFTA).

\section{References}

Cabrero Mendoza, Enrique. 2013. 'Fiscal Federalism in Mexico: Distortions and Structural Traps', Urban Public Economics Review, 18: 12-36.

Centro de Estudios de las Finanzas Públicas. 2019. Cuenta Pública 2018, Gasto Federalizado Ejercido en Entidades Federativas y Municipios, Cámara de Diputados.

Gershberg, Alec Ian. 1995. 'Fiscal Decentralization and Intergovernmental Relations: An Analysis of Federal versus State Education Finance in Mexico', Review of Urban and Regional Development Studies, 7(2): 119-42.

González Block, Miguel, et al. 2020. Mexico, Health System Review 2020, 22(2). World Health Organization. 
Graizbord, Boris. 2009. 'United Mexican States', in N. Steytler (ed.), Local Government and Metropolitan Regions in Federal Systems, pp. 200-33. Montreal and Kingston: McGill Queen's University Press.

Hopkins, Jack W. 1990. 'Intergovernmental Relations in Mexico and the United States: A Comparative Perspective', International Review of Administrative Sciences, 5: 403-20.

INEGI. 2010. Volumen y Crecimiento. Población total según tamaño de la localidad para cada entidad federativa, México.

Ministry of Health. 2020. Acuerdo por el que se declara como emergencia sanitaria por causa de fuerza mayor, a la epidemia de enfermedad generada por el virus SARS-CoV-2 (COVID-19). Official Gazette of the Federation, 30 March.

Parliamentary Gazette. 2020. 'Iniciativa con proyecto de decreto por el que se adicionan diversas disposiciones de la Ley Federal de Presupuesto y Responsabilidad Hacendaria, remitida por el titular del Ejecutivo federal' (Initiative with a draft decree that adds various provisions to the Federal Budget and Fiscal Responsibility Law, sent by the head of the federal Executive), Parliamentary Gazette of the Chamber of Deputies, 23 April.

Reforma, Mexico City. 2020. News reports between 18 March 2020 and 31 October 2020.

Rodríguez, Victoria E. 1998. 'Recasting Federalism in Mexico', Publius: The Journal of Federalism, 28(1): 235-54.

Serna de la Garza, José Maria. 2000. 'Constitutional Federalism in Latin America', California Western International Law Journal, 30(2): 277-301.

Serna de la Garza, José Maria. 2009. 'Mechanisms of Cooperation in Mexico's Federal System', in B. de Villiers (ed.), Crossing the Line: Dealing with Cross-Border Communities. Johannesburg: Konrad Adenauer Stiftung.

Serna de la Garza, José Maria. 2013. The Constitution of Mexico:A Contextual Analysis. United Kingdom: Hart Publishing.

Supreme Court of the Philippines. n.d. 'The Rule on the Writ of Amparo', http:// hrlibrary.umn.edu/research/Philippines/The\%20Rule\%20On\%20The\%20Writ\%20 Of\%20Amparo.pdf (accessed on 1 December 2020).

Ward, Peter and Victoria Rodríguez. 1999. 'New Federalism, Intra-Governmental Relations and Co-Governance in Mexico', Journal of Latin American Studies, 3(3): 673-710. 